\title{
SOLUSI PENANGANAN PEMBIAYAAN BERMASALAH DI BANK SYARIAH DALAM KONTEKS PERUNDANG-UNDANGAN REPUBLIK INDONESIA
}

\author{
Mochammad Afif \\ Universitas Islam Lamongan \\ e-mail: afiframadhan59@yahoo.com
}

\begin{abstract}
When the enactment of Act Number 7 of 1992 concerning banking there is another alternative form in addition to conventional banks that are known a bank based on the principle of profit sharing. Act Number 7 of 1992 concerning Banking has not yet used explicitly the term sharia bank or Islamic bank. The mention still uses the term "profit sharing principle". There is no more detailed provision regarding banks conducting business based on sharia principles. Financing is the majority of assets of sharia banks so that the financing must be maintained with quality based on the principle of prudence. The precautionary principle is a bank management guideline that must be adopted in order to realize a sound, robust and efficient banking system in accordance with the provisions of laws and regulations. Implementation of prudential principles by sharia banks is one of which is realized in performing a financing analysis that is analyzing confidence on the willingness and ability of prospective customers of the facility receiver to repay all obligations in time, before the Sharia Bank and/or UUS channel funds to the facility receiver. This confidence is derived from a careful assessment of the time, ability, capital, collateral, and business prospects of a potential customer (character, capacity, capital, collateral, condition). The sharia bank in providing financing hopes that the financing proceeds smoothly, the customer obeys what has been agreed upon in the agreement and pays in full when it matures. However, it can occur within the financing period of nonperforming financing. Efforts made by sharia bank to handle problematic financing by conducting a rescue of troubled financing with restructuring efforts if the customer still has good intentions in the sense of still willing to be invited to cooperate in efforts to save troubled financing, but if the customer has no conviction either in the sense cannot be invited in an effort to rescue nonperforming financing, sharia banks will make efforts to settle non-performing financing.
\end{abstract}

Keywords: Sharia Bank, Non Performing Financing, Handling Solution

\section{Pendahuluan}

Saat berlakunya Undang-Undang Nomor 7 tahun 1992 tentang Perbankan, ada bentuk alternatif lain di samping bank konvensional yang sudah dikenal masyarakat, yaitu bank yang berdasarkan pada prinsip bagi hasil. Undang-Undang Nomor 7 tahun 1992 tentang Perbankan sama sekali belum menggunakan secara tegas istilah bank syariah atau bank Islam. Penyebutannya masih menggunakan istilah "prinsip bagi hasil". Belum ada ketentuan yang lebih rinci mengenai bank yang melakukan kegiatan usaha berdasarkan prinsip syariah. ${ }^{1}$

\footnotetext{
${ }^{1}$ Sejak tanggal 16 Juli 2008 telah diundangkan Undang-Undang Nomor 21 tahun 2008 tentang Perbankan Syariah selanjutnya disebut dengan Undang Undang Perbankan Syariah.
} 
Seperti halnya bank konvensional, bank syariah berfungsi juga sebagai lembaga intermediasi (intermediary institution), yaitu berfungsi menghimpun dana dari masyarakat dan menyalurkan kembali dana-dana tersebut kepada masyarakat yang membutuhkannya dalam bentuk pembiayaan. Pembiayaan atau financing, yaitu pendanaan yang diberikan oleh suatu pihak kepada pihak lain untuk mendukung investasi yang telah direncanakan, baik dilakukan sendiri maupun lembaga. ${ }^{2}$

Pembiayaan adalah merupakan sebagian besar aset dari bank syariah sehingga pembiayaan tersebut harus dijaga kualitasnya, sebagaimana diamanatkan pada Pasal 2 Undang-Undang Perbankan Syariah bahwa perbankan syariah dalam melakukan kegiatan usahanya berasaskan prinsip syariah, demokrasi ekonomi dan prinsip kehati-hatian. Pada penjelasan Pasal 2 Undang-Undang Perbankan Syariah yang dimaksud dengan prinsip kehatihatian adalah pedoman pengelolaan bank yang wajib dianut guna mewujudkan perbankan yang sehat, kuat dan efisien sesuai dengan ketentuan peraturan perundang-undangan. Dari berbagai sumber dapat disimpulkan bahwa yang dimaksud dengan prinsip kehati-hatian adalah pengendalian risiko melalui penerapan peraturan perundang-undangan dan ketentuan yang berlaku secara konsisten. ${ }^{3}$

Sebagaimana diamanatkan pada Pasal 4 Undang-Undang Perbankan Syariah, keberadaan bank syariah di samping sebagai lembaga intermediasi seperti halnya bank konvensional, yaitu menghimpun dan menyalurkan dana masyarakat juga berfungsi sosial. Secara garis besar kegiatan operasional bank syariah dibagi menjadi 3 (tiga) kategori, yaitu: ${ }^{4}$

1. Kegiatan penghimpunan dana (funding)

Kegiatan penghimpunan dana dapat ditempuh oleh perbankan melalui mekanisme tabungan, giro, serta deposito. Khusus untuk perbankan syariah, tabungan dan giro dibedakan menjadi dua macam, yaitu tabungan dan giro berdasarkan pada akad wadi'ah dan tabungan dan giro yang didasarkan pada akad mudārabah. Sedangkan khusus deposito hanya memakai akad muḍārabah.

2. Kegiatan penyaluran dana (landing)

Kegiatan penyaluran dana kepada masyarakat (landing) dapat ditempuh bank dalam bentuk muḍ̄arabah, murābaḥah, mushārakah, ijārah ataupun qarḍ. Bank sebagai penyedia dana akan mendapatkan imbalan dalam bentuk margin keuntungan untuk muräbaḩah, bagi hasil untuk muḍarabah dan mushārakah, sewa untuk ijārah serta biaya administrasi untuk qard.

3. Jasa bank

Kegiatan usaha bank di bidang jasa dapat berupa penyediaan bank garansi (kafālah), letter of credit (L/C), ḥiwālah, wakālah dan jual beli valuta asing.

Perwujudan prinsip kehati-hatian diatur dalam rambu-rambu kesehatan sebagaimana pada Pasal 23 Undang-Undang Perbankan Syariah. Pada Pasal 23 (1) Undang-Undang Perbankan syariah mengatur bahwa bank syariah dan atau UUS harus mempunyai keyakinan atas kemauan dan kemampuan calon nasabah penerima fasilitas untuk melunasi seluruh

\footnotetext{
${ }^{2}$ Muhamad, Manajemen Pembiayaan Bank Syariah (Yogyakarta: UPP AMP YKPN, 2005), 17.

3 Yahman dan Trisadini Prasastinah Usanti, Bunga Rampai Hukum Aktual dalam Perspektif Hukum Bisnis Kontraktual Berimplikasi Pidana dan Perdata (Surabaya: Mitra Mandiri, 2011), 136.

${ }^{4}$ Abdul Ghofur Anshori, Perbankan Syariah Di Indoensia (Yogjakarta: Gadjah Mada University Press, 2007), 65 .
} 
kewajiban pada waktunya, sebelum bank syariah dan atau UUS menyalurkan dana kepada nasabah penerima fasilitas. Untuk mendapatkan keyakinan maka bank syariah wajib melakukan penilaian yang seksama terhadap watak, kemampuan, modal, $\operatorname{agunan}^{5}$, dan prospek usaha dari calon nasabah penerima fasilitas (character, capacity, capital, collateral, condition). Pada Pasal 36 Undang-Undang Perbankan Syariah diatur bahwa dalam memberikan pembiayaan dan melakukan kegiatan usaha lainnya, bank syariah dan UUS wajib menempuh cara-cara yang tidak merugikan bank syariah, UUS dan kepentingan nasabah yang mempercayakan dananya, sehingga bank syariah dalam memberikan pembiayaan wajib mempunyai keyakinan atas kemauan dan kemampuan dari nasabah penerima fasilitas. Adapun tujuan dari diberlakukannya prinsip kehati-hatian tidak lain agar bank-bank selalu dalam keadaan sehat, sehingga antara lain selalu dalam keadaan likuid, solvent dan menguntungkan (profitable). Dengan diberlakukannya prinsip kehati-hatian itu diharapkan kadar kepercayaan masyarakat terhadap perbankan selalu tinggi sehingga masyarakat bersedia dan tidak ragu-ragu menyimpan dananya di bank. ${ }^{6}$

Sebagian besar dana yang dipergunakan oleh bank syariah dalam menyalurkan dana dalam bentuk pembiayaan adalah dana nasabah penyimpan/nasabah investor ${ }^{7}$, sehingga dana nasabah penyimpan/nasabah investor wajib mendapat perlindungan hukum. Bilamana terjadi kegagalan dalam pembiayaan, maka sumber pelunasan pembiayaan adalah dari usaha nasabah yang menghasilkan pendapatan (revenue) yang disebut first way out dan second way out berupa agunan (collateral). Second way out berupa jaminan tertentu atas suatu benda, apabila terjadi pembiayaan bermasalah, bank berhak menjual benda agunan yang dibebani dengan hak jaminan dan mengambil hasil penjualan atas benda tersebut sebagai sumber pelunasan pembiayaan. Jaminan merupakan hal penting untuk diperhitungkan bagi bank karena jaminan merupakan sumber pelunasan bilamana nasabah mengalami kegagalan pembiayaan syariah.

Pembiayaan adalah suatu proses mulai dari analisis kelayakan pembiayaan sampai kepada realisasinya. Namun realisasi pembiayaan bukanlah tahap terakhir dari proses pembiayaan. Setelah realisasi pembiayaan, maka bank syariah perlu melakukan pemantauan dan pengawasan pembiayaan, karena dalam jangka waktu pembiayaan tidak mustahil terjadi pembiayaan bermasalah dikarenakan beberapa alasan. Bank syariah harus mampu menganalisis penyebab pembiayaan bermasalah sehingga dapat melakukan upaya untuk melancarkan kembali kualitas pembiayaan tersebut.

Proses pemberian pembiayaan pada bank syariah maka tahapan yang dilakukan oleh bank syariah tidak jauh berbeda dengan tahapan yang dilakukan oleh bank konvensional dalam memberikan kreditnya. Proses pemberian pembiayaan diawali dengan tahapan: ${ }^{8}$

\footnotetext{
${ }^{5}$ Pada Pasal 1.26 Undang-Undang Perbankan Syariah, agunan diberikan pengertian sebagai jaminan tambahan, baik berupa benda bergerak maupun tidak bergerak yang diserahkan oleh pemilik agunan kepada bank syariah dan/atau UUS guna menjamin pelunasan kewajiban nasabah penerima fasilitas.

${ }^{6}$ Sutan Remy Sjadeini, Kapita Selecta Hukum Perbankan, Jilid. 1 (t.t.p: t.p., t.th), 53.

${ }^{7}$ Nasabah penyimpan adalah nasabah yang menempatkan dananya di bank syariah dan/atau UUS dalam bentuk simpanan berdasarkan akad antara bank syariah atau UUS dan nasabah yang bersangkutan. Nasabah investor adalah nasabah yang menempatkan dananya di bank syariah dan/atau UUS dalam bentuk investasi berdasarkan akad antara bank syariah atau UUS dan nasabah bersangkutan.

${ }^{8}$ Trisadini Prasastinah Usanti dan A. Shomad, "Penyelesaian Pembiayaan Bermasalah Bank Syariah", (Laporan Penelitian - Unair Surabaya, 2008), 16.
} 
1. Tahap sebelum pemberian pembiayaan diputuskan oleh bank syariah, yaitu tahap bank syariah mempertimbangkan permohonan pembiayaan calon nasabah penerima fasilitas. Tahap ini disebut tahap analisis kelayakan penyaluran dana.

2. Tahap setelah permohonan pembiayaan diputuskan pemberiannya oleh bank syariah dan kemudian penuangan keputusan tersebut ke dalam perjanjian pembiayaan (akad pembiayaan) serta dilaksanakannya pengikatan agunan untuk pembiayaan yang diberikan itu. Tahap ini disebut tahap dokumentasi pembiayaan.

3. Tahap setelah perjanjian pembiayaan (akad pembiayaan) ditandatangani oleh kedua belah pihak dan dokumentasi pengikatan agunan telah selesai dibuat serta selama pembiayaan itu digunakan oleh nasabah penerima fasilitas sampai jangka waktu pembiayaan berakhir. Tahap ini disebut tahap penggunaan pembiayaan.

4. Tahap setelah pembiayaan menjadi bermasalah tetapi usaha nasabah penerima fasilitas masih memiliki prospek sehingga pembiayaan yang bermasalah itu dapat diselamatkan untuk menjadi lancar kembali. Tahap ini disebut tahap penyelamatan pembiayaan.

5. Tahap setelah pembiayaan menjadi macet. Tahap ini disebut tahap penyelesaian pembiayaan.

\section{Kriteria Pembiayaan Bermasalah}

Pembiayaan yang telah disetujui oleh bank syariah dan dinikmati oleh nasabah, maka peranan bank syariah lebih berat dibandingkan pada saat dana tersebut belum mengucur di tangan nasabah. Untuk menghindari terjadinya kegagalan pembiayaan, maka bank syariah harus melakukan pembinaan dan regular monitoring, yaitu dengan cara monitoring aktif dan monitoring pasif. Monitoring aktif yaitu mengunjungi nasabah secara regular, memantau laporan keuangan secara rutin dan memberikan laporan kunjungan nasabah/call report kepada komite pembiayaan/supervisor. Sedangkan monitoring pasif yaitu memonitoring pembayaran kewajiban nasabah kepada bank syariah setiap akhir bulan. Bersamaan pula diberikan pembinaaan dengan memberikan saran, informasi maupun pembinaan teknis yang bertujuan untuk menghindari pembiayaan bermasalah.

Pada jangka waktu (masa) pembiayaan tidak mustahil terjadi suatu kondisi pembiayaan, yaitu adanya suatu penyimpangan utama dalam hal pembayaran yang menyebabkan keterlambatan dalam pembayaran atau diperlukan tindakan yuridis dalam pengembalian atau kemungkinan potensial loss. Kondisi ini yang disebut dengan pembiayaan bermasalah, keadaan turunnya mutu pembiayaan tidak terjadi secara tiba-tiba akan tetapi selalu memberikan warning sign atau faktor-faktor penyebab terlebih dahulu dalam masa pembiayaan. Ada beberapa faktor penyebab pembiayaan bermasalah: ${ }^{9}$

1. Faktor intern (berasal dari pihak bank)

a. Kurang baiknya pemahaman atas bisnis nasabah.

b. Kurang dilakukan evaluasi keuangan nasabah.

c. Kesalahan setting fasilitas pembiayaan (berpeluang melakukan side streaming). ${ }^{10}$

d. Perhitungan modal kerja tidak didasarkan kepada bisnis usaha nasabah.

\footnotetext{
${ }^{9}$ Ibid., 33-35.

${ }^{10}$ Dana digunakan oleh nasabah tidak sesuai dengan peruntukkan pembiayaan yang telah disepakati dalam perjanjian.
} 
e. Proyeksi penjualan terlalu optimis.

f. Proyeksi penjualan tidak memperhitungkan kebiasaan bisnis dan kurang memperhitungkan aspek kompetitor.

g. Aspek jaminan tidak diperhitungkan aspek marketable.

h. Lemahnya supervisi dan monitoring.

i. Terjadinya erosi mental. Kondisi ini dipengaruhi timbali balik antara nasabah dengan pejabat bank sehingga mengakibatkan proses pemberian pembiayaan tidak didasarkan pada praktek perbankan yang sehat.

2. Faktor ekstern

a. Karakter nasabah tidak amanah (tidak jujur dalam memberikan informasi dan laporan tentang kegiatannya).

b. Melakukan side streaming penggunaan dana.

c. Kemampuan pengelolaan nasabah tidak memadai sehingga kalah dalam persaingan usaha.

d. Usaha yang dijalankan relatif baru.

e. Bidang usaha nasabah telah jenuh.

f. Tidak mampu menanggulangi masalah/kurang menguasai bisnis.

g. Meninggalnya key person.

h. Perselisihan sesama direksi.

i. Terjadi bencana alam.

j. Adanya kebijakan pemerintah. Peraturan suatu produk atau sektor ekonomi atau industri dapat berdampak positif maupun negatif bagi perusahaan yang berkaitan dengan industri tersebut.

Kualitas pembiayaan ditetapkan menjadi 5 (lima) golongan, yaitu lancar, dalam perhatian khusus, kurang lancar, diragukan dan macet, yang dikategorikan pembiayaan bermasalah adalah kualitas pembiayaan yang mulai masuk golongan dalam perhatian khusus sampai golongan macet. Bank syariah wajib untuk menggolongkan kualitas aktiva produktif ${ }^{11}$ sesuai dengan kriterianya dan dinilai secara bulanan, sehingga jika bank syariah tidak melakukannya, maka akan dikenakan sanksi administratif sebagaimana dimaksud Pasal 56 Undang-Undang Perbankan Syariah.

Bilamana terjadi pembiayaan bermasalah maka bank syariah akan melakukan upaya untuk menangani pembiayaan bermasalah tersebut dengan melakukan upaya penyelamatan dan penyelesaian pembiayaan bermasalah, agar dana yang telah disalurkan oleh bank syariah dapat diterima kembali. Akan tetapi mengingat dana yang dipergunakan oleh bank syariah dalam memberikan pembiayaan berasal dari dana masyarakat yang ditempatkan pada bank syariah, maka bank syariah dalam memberikan pembiayaan wajib menempuh cara-cara yang

\footnotetext{
${ }^{11}$ Berdasarkan Peraturan Bank Indonesia Nomor 9/9/PBI/2007 tentang Perubahan atas Peraturan Bank Indonesia Nomor 8/21/PBI/2006 tentang Penilaian Kualitas Aktiva Bank Umum Yang Melaksanakan Kegiatan Usaha Berdasarkan Prinsip Syariah, bahwa yang dimaksud dengan aktiva produktif adalah penanaman dana bank baik dalam rupiah maupun valuta asing untuk memperoleh penghasilan, dalam bentuk pembiayaan, surat berharga syariah, penempatan, penyertaan modal, penyertaan modal sementara, komitmen dan kontinjensi pada transaksi rekening administratif, sertifikat wadiah Bank Indonesia serta bentuk penyediaan dana lainnya yang dapat dipersamakan dengan itu.
} 
tidak merugikan bank syariah dan atau UUS dan kepentingan nasabahnya yang telah mempercayakan dananya.

\section{Penyelamatan Pembiayaan Bermasalah}

Bank syariah dalam memberikan pembiayaan berharap bahwa pembiayaan tersebut berjalan dengan lancar, nasabah mematuhi apa yang telah disepakati dalam perjanjian dan membayar lunas bilamana jatuh tempo. Akan tetapi bisa terjadi dalam jangka waktu pembiayaan nasabah mengalami kesulitan dalam pembayaran yang berakibat kerugian bagi bank syariah. ${ }^{12}$ Dalam hukum perdata, kewajiban memenuhi prestasi harus dipenuhi oleh debitur, sehingga jika debitur tidak memenuhi sesuatu yang diwajibkan seperti yang telah ditetapkan dalam perjanjian maka dikatakan debitur telah melakukan wanprestasi. Ada empat keadaan dikatakan wanprestasi yaitu: ${ }^{13}$

1. Debitur tidak memenuhi prestasi sama sekali.

2. Debitur memenuhi prestasi tidak sebagaimana yang diperjanjikan.

3. Debitur terlambat memenuhi prestasi.

4. Debitur melakukan perbuatan yang tidak diperbolehkan dalam perjanjian.

Keberlangsungan usaha suatu bank yang didominasi oleh aktivitas pembiayaan, dipengaruhi oleh kualitas pembiayaan yang merupakan sumber utama bank dalam menghasilkan pendapatan dan sumber dana untuk ekspansi usaha yang berkesinambungan. Pengelolaan bank yang optimal dalam aktivitas pembiayaan dapat meminimalisasi potensi kerugian yang akan terjadi. Pengelolaan tersebut antara lain dilakukan melalui restrukturisasi pembiayaan terhadap nasabah yang mengalami penurunan kemampuan membayar namun dinilai masih memiliki prospek usaha dan mempunyai kemampuan untuk membayar setelah restrukturisasi. Pelaksanaan restrukturisasi pembiayaan pada bank, harus tetap memenuhi prinsip syariah di samping mengacu kepada prinsip kehati-hatian yang bersifat universal yang berlaku pada industri perbankan. Selain itu, aspek kebutuhan dan kesesuaian dengan perkembangan industri perbankan syariah menjadi pertimbangan dalam penyempurnaan ketentuan mengenai restrukturisasi pembiayaan di bank syariah dan unit usaha syariah. ${ }^{14}$

Setiap terjadi pembiayaan bermasalah maka bank syariah akan berupaya untuk menyelamatkan pembiayaan, berdasarkan Peraturan Bank Indonesia Nomor 13/9/PBI/2011 tentang Perubahan atas Peraturan Bank Indonesia Nomor 10/PBI/2008 tentang Restrukturisasi Pembiayaan Bagi Bank Syariah dan Unit Usaha Syariah. Restrukturisasi pembiayaan adalah upaya yang dilakukan bank dalam rangka membantu nasabah agar dapat menyelesaikan kewajibannya, antara lain melalui:

1. Penjadwalan kembali (rescheduling), yaitu perubahan jadwal pembayaran kewajiban nasabah atau jangka waktunya; ${ }^{15}$

\footnotetext{
12 Trisadini Prasastinah Usanti,"Karakteristik Prinsip Kehati-Hatian Pada Kegiatan Usaha Perbankan Syariah", (Disertasi--Universitas Airlangga, Surabaya, 2010), 244.

${ }^{13}$ Setiawan, Pokok-Pokok Hukum Perikatan (Bandung: Binacipta, 1979), 18.

${ }^{14}$ Penjelasan Peraturan Bank Indonesia Nomor 13/9/PBI/2011 tentang Perubahan atas Peraturan Bank Indonesia Nomor 10/PBI/2008 tentang Restrukturisasi Pembiayaan Bagi Bank Syariah dan Unit Usaha Syariah.

15 Berdasarkan SEBI No.13/18/DPbS tanggal 30 Mei 2011, yang dimaksud dengan penjadwalan kembali (rescheduling), yaitu perubahan jadwal pembayaran kewajiban nasabah atau jangka waktunya, tidak termasuk perpanjangan atas pembiayaan muḍārabah atau mushārakah yang memenuhi kualitas lancar dan telah jatuh tempo serta bukan disebabkan nasabah mengalami penurunan kemampuan membayar.
} 
2. Persyaratan kembali (reconditioning), yaitu perubahan sebagian atau seluruh persyaratan pembiayaan tanpa menambah sisa pokok kewajiban nasabah yang harus dibayarkan kepada bank, antara lain meliputi:
a. Perubahan jadwal pembayaran.
b. Perubahan jumlah angsuran.
c. Perubahan jangka waktu.
d. Perubahan nisbah dalam pembiayaan muḍārabah atau mushārakah.
e. Perubahan proyeksi bagi hasil dalam pembiayaan muḍāabah atau mushārakah.
f. Pemberian potongan.

3. Penataan kembali (restructuring), yaitu perubahan persyaratan pembiayaan yang antara lain meliputi:

a. Penambahan dana fasilitas pembiayaan bank.

b. Konversi akad pembiayaan.

c. Konversi pembiayaan menjadi surat berharga syariah berjangka waktu menengah.

d. Konversi pembiayaan menjadi penyertaan modal sementara pada perusahaan nasabah $^{16}$, yang dapat disertai dengan rescheduling atau reconditioning.

Berdasarkan SEBI No.13/18/DPBS tanggal 30 Mei 2011 tentang Perubahan atas SEBI Nomor 10/34/DPbS tanggal 22 Oktober 2008 tentang Restrukturisasi Pembiayaan Bagi Bank Syariah dan Unit Usaha Syariah bahwa Bank Uumum Syariah (BUS) atau Unit Usaha Syariah (UUS) akan menghentikan akad pembiayaan dalam bentuk piutang murābahah atau piutang istiṣn $\vec{a}$ dengan memperhitungkan nilai wajar obyek muräbahah atau istịnnả. Dalam hal terdapat perbedaan antara jumlah kewajiban nasabah dengan nilai wajar obyek muräbaḥah atau istișna , maka diakui sebagai berikut:

1. Apabila nilai wajar lebih kecil daripada jumlah kewajiban nasabah, maka sisa kewajiban nasabah tersebut tetap menjadi hak BUS atau UUS, yang penyelesaiannya disepakati antara BUS atau UUS dan nasabah.

2. Apabila nilai wajar lebih besar daripada jumlah kewajiban nasabah, maka selisih nilai tersebut diakui sebagai uang muka ijärah muntahiyah bi al-tamlik atau menambah porsi modal nasabah untuk mushārakah atau mengurangi modal muḍārabah dari BUS atau UUS.

Bank hanya dapat melakukan restrukturisasi pembiayaan terhadap nasabah yang memenuhi kriteria sebagai berikut:

1. Nasabah mengalami penurunan kemampuan pembayaran; dan

2. Nasabah memiliki prospek usaha yang baik dan mampu memenuhi kewajiban setelah restrukturisasi.

Restrukturisasi untuk pembiayaan konsumtif hanya dapat dilakukan untuk nasabah yang memenuhi kriteria sebagai berikut:

1. Nasabah mengalami penurunan kemampuan pembayaran; dan

\footnotetext{
${ }^{16}$ Penyertaan modal sementara adalah penyertaan modal BUS atau UUS, antara lain berupa pembelian saham dan/atau konversi pembiayaan menjadi saham dalam perusahaan nasabah untuk mengatasi kegagalan penyaluran dana dan/atau piutang dalam jangka waktu tertentu sebagaimana dimaksud dalam ketentuan Bank Indonesia yang berlaku.
} 
2. Terdapat sumber pembayaran angsuran yang jelas dari nasabah dan mampu memenuhi kewajiban setelah restrukturisasi.

Restrukturisasi pembiayaan wajib didukung dengan analisis dan bukti-bukti yang memadai serta didokumentasikan dengan baik. Di samping dua kriteria di atas, maka bank syariah akan melakukan penyelamatan pembiayaan bermasalah dengan upaya restrukturisasi apabila nasabah masih mempunyai i’tikad baik, dalam arti masih mau diajak kerjasama dalam upaya penyelamatan pembiayaan bermasalah. Akan tetapi jika nasabah sudah tidak beri'tikad baik. dalam arti tidak dapat diajak kerjasama dalam upaya penyelamatan pembiayaan bermasalah maka bank syariah akan melakukan upaya penyelesaian pembiayaan bermasalah.

Adapun landasan syariah dari upaya restrukturisasi pembiayaan yaitu:

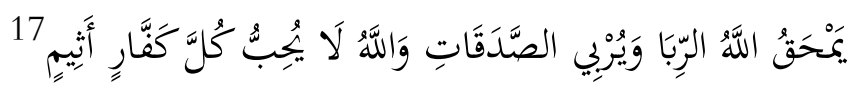

"Allah memusnahkan riba dan menyuburkan sedekah dan Allah tidak menyukai setiap orang yang tetap dalam kekafiran dan selalu berbuat dosa".

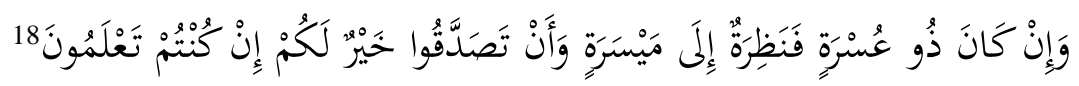

"Dan jika (orang berhutang itu) dalam kesukaran, maka berilah tangguh sampai dia berkelapangan. Dan menyedekahkan (sebagian atau semua hutang) itu lebih baik bagimu, jika kamu mengetahui”.

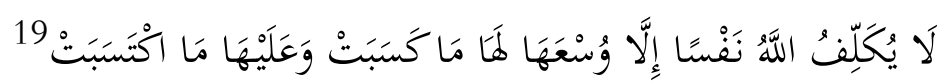

"Allah tidak membebani seseorang melainkan sesuai dengan kesanggupannya. Ia mendapat pahala (atas kebajikan) yang diusahakannya dan ia mendapat siksa (dari kejahatan) yang dikerjakannya".

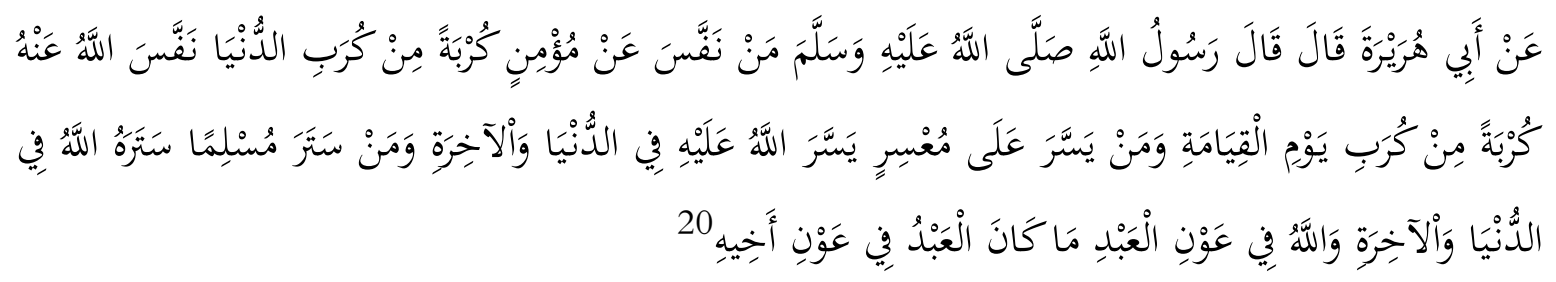

\footnotetext{
${ }^{17}$ al-Baqārah, 2: 276.

${ }^{18}$ Ibid., 2: 280.

${ }^{19}$ Ibid., 2: 286.

${ }^{20}$ Muslim ibn al-Hajjāj Abū al-Ḥasan al-Qushayri al-Nisābūri, Saḥīh Muslim, Juz 4 (Beirut: Dār Ihyyā al-Turāth al-'Arabiy, t.th), 2074.
} 
"Barang siapa yang membebaskan seorang mukmin dari himpitan kehidupan di dunia, maka Allah akan membebaskannya kelak dari himpitan di hari akhir. Dan barang siapa yang memudahkan orang yang sedang dalam kesulitan, maka Allah akan memudahkannya kesulitannya di dunia dan di akhirat. Dan barang siapa yang menutupi aib seorang muslim, maka Allah pun akan menutupi aibnya di dunia dan di akhirat. Dan Allah akan selalu menolong seorang hamba, selagi hamba tersebut selalu menolong saudaranya”.

\section{Penyelesaian Pembiayaan Bermasalah}

1. Penyelesaian Melalui Eksekusi Jaminan

Penyelesaian melalui jaminan dilakukan oleh bank syariah bilamana berdasarkan evaluasi ulang pembiayaan, prospek usaha nasabah tidak ada, dan atau nasabah tidak kooperatif untuk menyelesaikan pembiayaan atau upaya penyelamatan dengan upaya restrukturisasi tidak membawa hasil melancarkan kembali pembiayaan tersebut. Maka upaya penyelesaian pembiayaan bermasalah dengan cara eksekusi jaminan akan dilakukan oleh bank syariah.

Eksekusi jaminan disesuaikan dengan lembaga jaminan yang membebani benda jaminan tersebut, rahn (gadai syariah), jaminan hipotik, jaminan hak tanggungan, dan jaminan fidusia. Pada jaminan hipotik, eksekusi agunan diatur pada Pasal 1178 BW. Pada jaminan hak tanggungan berdasarkan Pasal 20 Undang-Undang No. 4 Tahun 1996, bilamana debitor cidera janji, maka ada tiga alternatif yang dapat dilakukan oleh bank, yaitu:

a. Berdasarkan hak pemegang hak tanggungan pertama untuk menjual obyek hak tanggungan sebagaimana dimaksud dalam pasal 6.

b. Berdasarkan titel eksekutorial yang terdapat dalam sertifikat hak tanggungan sebagaimana pada pasal 14 (2) bahwa obyek hak tanggungan dijual melalui pelelangan umum menurut tata cara yang ditentukan dalam peraturan perundangundangan untuk pelunasan piutang pemegang hak tanggungan dengan hak mendahulu dari para kreditor-kreditor lainnya.

c. Atas kesepakatan penjualan obyek jaminan dapat dilaksanakan di bawah tangan jika dengan cara demikian akan dapat diperoleh harga tertinggi.

Pada jaminan fidusia berdasarkan Pasal 29 Undang-Undang Nomor 42 Tahun 1999, apabila debitor wanprestasi maka obyek jaminan dapat dieksekusi dengan cara:

a. Pelaksanaan titel eksekutorial.

b. Penjualan benda yang menjadi obyek jaminan fidusia atas kekuasaan penerima fidusia sendiri melalui pelelangan umum.

c. Penjualan di bawah tangan berdasarkan kesepakatan.

Di Undang-Undang Perbankan Syariah pada Pasal 40, bank syariah dan UUS dapat membeli sebagian maupun seluruh agunan, baik melalui pelelangan maupun di luar pelelangan, berdasarkan penyerahan secara sukarela oleh pemilik agunan, atau berdasarkan pemberian kuasa untuk menjual dari pemilik agunan, dengan ketentuan agunan yang dibeli tersebut wajib dicairkan selambat-lambatnya dalam jangka waktu satu tahun. ${ }^{21}$ Dalam hal harga pembelian agunan melebihi jumlah kewajiban nasabah kepada

\footnotetext{
${ }^{21}$ Tujuan pembelian oleh bank adalah untuk membantu mempercapat penyelesaian kewajiban nasabah. Agunan
} 
bank syariah dan UUS, selisih kelebihan jumlah tersebut harus dikembalikan kepada nasabah setelah dikurangi dengan biaya lelang dan biaya lain yang terkait langsung dengan proses pembelian agunan.

Landasan syariah yang berkaitan dengan jaminan adalah:

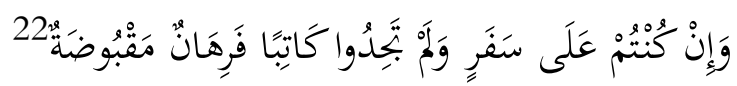

"Jika kamu dalam perjalanan (dan kamu bermuamalah/jual beli tidak secara tunai), sedang kamu tidak memperoleh seorang penulis, maka hendaklah ada barang tanggungan yang dipegang oleh si berpiutang..."

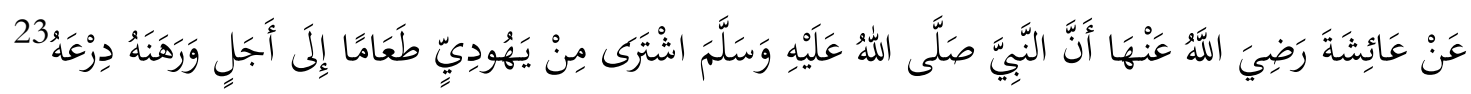

"Dari Aisyah bahwasanya Nabi Muhammad SAW pernah membeli bahan makanan dari seorang yahudi dengan hutang dan beliau memberikan baju besinya sebagai jaminan".

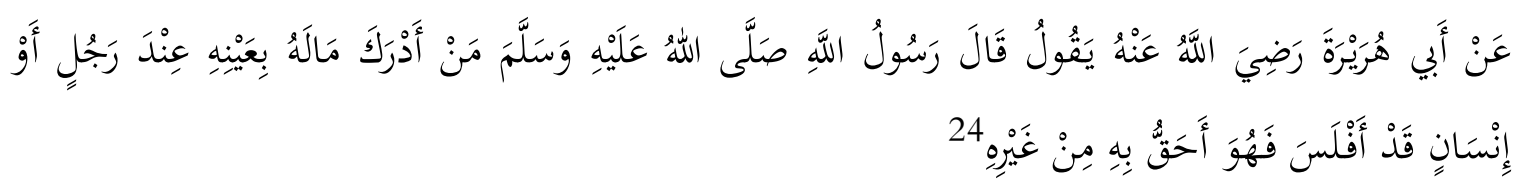

"Siapapun yang bangkrut (muflis), lalu kreditornya mendapatkan barangnya sendiri pada si muflis, maka kreditor itu lebih berhak untuk menarik kembali barangnya daripada orang lain.”

2. Penyelesaian lewat Badan Arbitrase Syariah Nasional

Berdasarkan klausula dalam perjanjian pembiayaan, jika salah satu pihak tidak menunaikan kewajibannya atau terjadi perselisihan di antara kedua belah pihak dan tidak tercapai kesepakatan melalui musyawarah, maka penyelesainya melalui Badan Arbitrase Syariah Nasional (BASYARNAS) ${ }^{25}$ BASYARNAS berwenang:

a. Menyelesaikan secara adil dan cepat sengketa muamalah (perdata) yang timbul dalam bidang perdagangan, keuangan, industri, jasa dan lain-lain yang menurut hukum dan peraturan perundang-undangan dikuasai sepenuhnya oleh pihak yang

yang dapat dibeli oleh bank adalah agunan yang pembiayaannya dikategorikan macet selama jangka waktu tertentu.

22 al-Baqārah, 2: 283.

${ }^{23}$ Muhạmmad ibn Ismā'ìl Abu 'Abdillāh al-Bukhāriy, Șaḥiḥ al-Bukhāriy, Juz 3, (Beirut: Dār al-Fikr, 1442 H), 142.

${ }^{24}$ Ibid., 118.

25 Semua fatwa Dewan Syariah Nasional (DSN) Majelis Ulama Indonesia (MUI) sebelum tahun 2008 selalu mencantumkan penyelesaiannya lewat Badan Arbitrasi Syariah Nasional, akan tetapi sejak tahun 2008 dalam fatwa dicantumkan: "Jika salah satu pihak tidak menunaikan kewajibannya atau jika terjadi perselisihan di antara para pihak, maka penyelesaiannya dilakukan melalui Badan Arbitrasi Syariah Nasional atau pengadilan agama setelah tidak tercapai kesepakatan melalui musyawarah. 
bersengketa, dan para pihak sepakat secara tertulis untuk menyerahkan penyelesaiannya kepada BASYARNAS sesuai dengan prosedur BASYARNAS.

b. Memberikan pendapat yang mengikat atas permintaan para pihak tanpa adanya suatu sengketa mengenai persoalan berkenan dengan suatu perjanjian. ${ }^{26}$

Kesepakatan untuk menyerahkan penyelesaian sengketa kepada BASYARNAS, dilakukan oleh pihak:

a. Dengan mencantumkan klausula arbitase dalam suatu naskah perjanjian; atau

b. Dengan perjanjian arbitrase tersendiri yang dibuat dan disetujui oleh para pihak, baik sebelum maupun sesudah timbul sengketa.

Keputusan arbitrase merupakan keputusan terkahir dan mengikat (final and biding). Landasan syariah arbitrase bisa merujuk kepada:

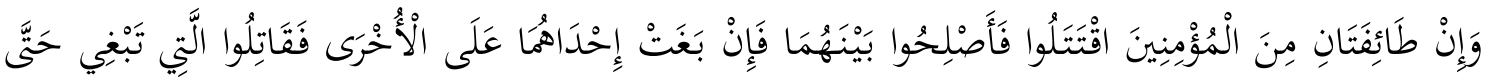

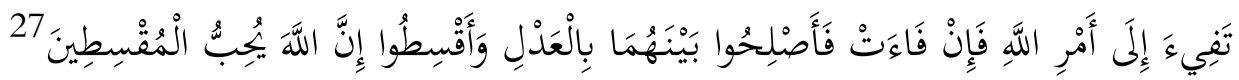

"Jika dua golongan orang yang beriman berperang (bersengketa), maka damaikan keduanya. Jika salah satu dari keduanya berbuat aniaya terhadap yang lain, maka perangilah golongan yang berbuat aniaya itu sampai mereka kembali kepada ajaran Allah. Dan jika golongan itu telah kembali, maka damaikan keduanya dengan adil dan berlakulah adil. Sesungguhnya Allah menyukai orang-orang yang berlaku adil”".

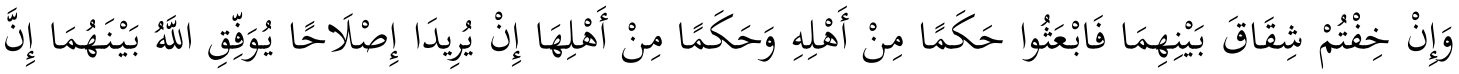

$$
\begin{aligned}
& \text { اللَّهَ كَانَ عَلِيمًا خَبِيركا }
\end{aligned}
$$

"Jika kamu khawatir terjadi sengketa diantara keduanya (suami istri), maka kirimkan seorang hakam dari keluarga laki-laki dan seorang hakam dari keluarga perempuan. Jika kedua hakam itu bermaksud mengadakan perbaikan (perdamaian), niscaya Allah akan memberi taufik kepada suami-istri itu. Sesungguhnya Allah Maha Mengetahui lagi Maka Mengenal".

\section{Penyelesaian Lewat Litigasi}

Penyelesaian lewat litigasi akan ditempuh oleh bank jika nasabah tidak beri'tikad baik, yaitu tidak menunjukkan kemauan untuk memenuhi kewajibannya sedangkan nasabah sebenarnya masih mempunyai harta kekayaan lain yang tidak dikuasai oleh bank atau sengaja disembunyikan atau mempunyai sumber-sumber lain untuk menyelesaikan kredit macetnya. ${ }^{29}$ Sejak diundangkannya Undang-Undang Nomor 3 tahun 2006 tentang Peradilan Agama, maka jika terjadi sengketa dalam bidang muamalah maka diselesaikan lewat pengadilan agama.

\footnotetext{
${ }^{26}$ Profil dan Prosedur Badan Arbitase Syariah Nasional (BASYARNAS), 9.

27 al-Quran, 49: 9.

${ }^{28}$ Ibid., 4: 35.

${ }^{29}$ Sutan Remy Sjadeini, Kapita Selecta, 103.
} 
Tujuan dari keberadaan peradilan agama adalah bertugas dan berwenang memeriksa, memutus dan menyelesaikan perkara di tingkat pertama antara orang-orang beragama Islam di bidang perkawinan, waris, wasiat, hibah, wakaf, zakat, infaq, shadaqah dan ekonomi syariah.

Perubahan penting yang terdapat dalam Undang-Undang Nomor 3 tahun 2006 adalah perluasan kekuasaan atau kewenangan pengadilan agama yang meliputi juga sengketa di bidang ekonomi syariah, hal ini terdapat pada Pasal 49 Undang-Undang Nomor 3 tahun 2006. Yang dimaksud dengan ekonomi syariah adalah perbuatan atau kegiatan usaha yang dilaksanakan menurut syariah, meliputi:

a. Bank syariah

b. Asuransi syariah

c. Reasuransi syariah

d. Reksa dana syariah

e. Obligasi syariah dan surat berharga berjangka menengah syariah

f. Sekuritas syariah

g. Pembiayaan syariah

h. Pegadaian syariah

i. Dana pensiun lembaga keuangan syariah

j. Bisnis syariah

k. Lembaga keuangan mikro syariah

Sebelum diberlakunya Undang-Undang Nomor 3 tahun 2006 sengketa ekonomi syariah tidak dapat diselesaikan di pengadilan agama, karena wewenang pengadilan agama dibatasi oleh Undang-Undang Nomor 7 tahun 1989 yang hanya dapat memeriksa, memutus dan menyelesaiakan perkara-perkara yang menyangkut perkawinan, warisan, wasiat, hibah, wakaf dan shadaqah. Artinya pengadilan agama tidak dapat memeriksa, memutus dan menyelesaikan perkara-perkara di luar keenam bidang tersebut. Sehingga apabila ada sengketa ekonomi syariah, para pihak dapat menyelesaikan di pengadilan negeri (jalur litigasi) atau di Badan Arbitrase Syariah Nasional (jalur non litigasi). Kewenangan pengadilan agama yang dipaparkan oleh Undang-Undang Nomor 3 tahun 2006 ini memberikan kejelasan dan kepastian bagi masyarakat maupun pelaku ekonomi syariah.

Dalam perkembangannya, dengan Undang-Undang Perbankan Syariah pada Pasal 55 ditentukan bahwa:

1. Penyelesaian sengketa perbankan syariah dilakukan oleh pengadilan dalam lingkungan peradilan agama.

2. Dalam hal para pihak telah memperjanjikan penyelesaian sengketa selain sebagaimana dimaksud pada ayat (1), penyelesaian sengketa dilakukan sesuai dengan isi akad.

3. Penyelesaian sengketa sebagaimana dimaksud pada ayat (2) tidak boleh bertentangan dengan prinsip syariah.

Dalam penjelasan umum dijelaskan bahwa penyelesaian yang mungkin timbul pada perbankan syariah, akan dilakukan melalui pengadilan di lingkungan peradilan agama. Di samping itu, dibuka pula kemungkinan penyelesaian sengketa melalui musyawarah, mediasi perbankan, lembaga arbitrase atau melalui pengadilan di lingkungan peradilan umum sepanjang disepakati di dalam akad oleh para pihak. Sedangkan dalam penjelasan pasal demi 
pasal dijelaskan yang dimaksud dengan penyelesaian sengketa dilakukan sesuai dengan isi Akad adalah upaya sebagai berikut:

1. Musyawarah

2. Mediasi perbankan

3. Melalui Badan Arbitrase Syariah Nasional (Basyarnas) atau lembaga arbitrase lain; dan/atau

4. Melalui pengadilan dalam lingkungan peradilan umum

Pemberlakuan Undang-Undang Perbankan Syariah khususnya Pasal 55 dan penjelasannya telah mereduksi kewenangan pengadilan agama dalam menyelesaikan sengketa di bank syariah, karena dimungkinkan penyelesaian sengketa melalui pengadilan dalam lingkungan peradilan umum sepanjang disepakati di dalam akad oleh para pihak. Prinsip kăffah yang terkandung pada penjelasan pasal 3 Undang-Undang Perbankan Syariah ${ }^{30}$ seharusnya betul-betul diterapkan tidak saja dalam produk-produk yang ditawarkan oleh bank syariah akan tetapi juga dalam penyelesaian sengketanya dilakukan melalui pengadilan di lingkungan peradilan agama.

\section{Hapus Buku dan Hapus Tagih}

Hapus buku adalah tindakan administratif bank untuk menghapus buku pembiayaan yang memiliki kualitas macet dari neraca sebesar kewajiban nasabah tanpa menghapus hak tagih bank kepada nasabah. Hapus tagih adalah tindakan bank menghapus kewajiban nasabah yang tidak dapat diselesaikan, dalam arti kewajiban nasabah dihapuskan tidak tertagih kembali. ${ }^{31}$ Hapus buku dan hapus tagih hanya dapat dilakukan terhadap pembiayaan yang memiliki kualitas macet. Hapus buku tidak dapat dilakukan terhadap sebagian pembiayaan (partial write off), sedangkan hapus tagih dapat dilakukan baik untuk sebagian atau seluruh pembiayaan. Hapus tagih terhadap sebagian pembiayaan hanya dapat dilakukan dalam rangka restrukturisasi pembiayaan atau dalam rangka penyelesaian pembiayaan. Hapus buku dan/atau hapus tagih hanya dapat dilakukan setelah bank syariah melakukan berbagai upaya untuk memperoleh kembali aktiva produktif yang diberikan.

\section{Kesimpulan}

Pembiayaan merupakan sebagian besar aset dari bank syariah sehingga pembiayaan tersebut harus dijaga kualitasnya dengan mendasarkan pada prinsip kehati-hatian. Prinsip kehati-hatian adalah pedoman pengelolaan bank yang wajib dianut guna mewujudkan perbankan yang sehat, kuat dan efisien sesuai dengan ketentuan peraturan perundangundangan. Penerapan prinsip kehati-hatian oleh bank syariah dan/atau UUS salah satunya diwujudkan dalam melakukan analisa pembiayaan, yaitu menganalisa keyakinan atas kemauan dan kemampuan calon nasabah penerima fasilitas untuk melunasi seluruh kewajiban pada waktunya, sebelum bank syariah dan/atau UUS menyalurkan dana kepada nasabah penerima fasilitas. Keyakinan tersebut diperoleh dari penilaian dengan seksama terhadap

30 Pasal 3 Undang-Undang Perbankan Syariah bahwa dalam mencapai tujuan menunjang pelaksanaan pembangunan nasional, perbankan syariah tetap berpegang pada prinsip syariah secara keseluruhan (käffah) dan konsisten (istiqāmah).

${ }^{31}$ Hapus tagih merupakan salah satu cara dari hapusnya perikatan sebagaimana diatur pada Pasal 1318 BW. 
watak, kemampuan, modal, agunan, dan prospek usaha dari calon nasabah penerima fasilitas (character, capacity, capital, collateral, condition). Bank syariah dalam memberikan pembiayaan berharap bahwa pembiayaan tersebut berjalan dengan lancar, nasabah mematuhi apa yang telah disepakati dalam perjanjian dan membayar lunas jika jatuh tempo. Akan tetapi bisa terjadi dalam jangka waktu pembiayaan timbul pembiayaan bermasalah. Upaya yang dilakukan oleh bank syariah untuk menangani pembiayaan bermasalah dengan melakukan penyelamatan pembiayaan bermasalah dengan upaya restrukturisasi apabila nasabah masih mempunyai i'tikad baik, dalam arti masih mau diajak kerjasama dalam upaya penyelamatan pembiayaan bermasalah, akan tetapi jika nasabah sudah tidak beri'tikad baik, dalam arti tidak dapat diajak kerjasama dalam upaya penyelamatan pembiayaan bermasalah maka bank syariah akan melakukan upaya penyelesaian pembiayaan bermasalah.

\section{Daftar Rujukan}

Anshori, Abdul Ghofur. Perbankan Syariah Di Indonesia. Yogjakarta: Gadjah Mada University Press, 2007.

Muhamad. Manajemen Pembiayaan Bank Syariah. Yogyakarta: UPP AMP YKPN, 2005.

Peraturan Bank Indonesia Nomor 9/9/PBI/2007 tentang Perubahan atas Peraturan Bank Indonesia Nomor 8/21/PBI/2006 tentang Penilaian Kualitas Aktiva Bank Umum yang Melaksanakan Kegiatan Usaha Berdasarkan Prinsip Syariah.

Peraturan Bank Indoensia Nomor 13/9/PBI/2011 tentang Perubahan atas Peraturan Bank Indonesia Nomor 10/PBI/2008 tentang Restrukturisasi Pembiayaan Bagi Bank Syariah dan Unit Usaha Syariah.

Profil dan Prosedur Badan Arbitase Syariah Nasional (BASYARNAS).

SEBI No.13/18/DPbS tanggal 30 Mei 2011 tentang Perubahan atas SEBI Nomor 10/34/DPbS

tanggal 22 Oktober 2008 tentang Restrukturisasi Pembiayaan Bagi Bank Syariah dan Unit Usaha (UUS).

Setiawan. Pokok-Pokok Hukum Perikatan. Bandung: Bina Cipta, 1979.

Sjahdeini, Sutan Remy. Kapita Selecta Hukum Perbankan, Jilid I. t.t.p: t.p, t.th.

Undang-Undang Nomor 4 Tahun 1996 tentang Hak Tanggungan atas Tanah Beserta Benda-

Benda yang Berkaitan Dengan Tanah.

Undang-Undang Nomor 42 Tahun 1999 tentang Jaminan Fidusia.

Undang-Undang Nomor 3 Tahun 2006 tentang Perubahan Atas Undang-Undang Nomor 7

Tahun 1989 tentang Peradilan Agama, LN RI Tahun 2006 Nomor 22.

Undang-Undang Nomor 21 Tahun 2008 Tentang Perbankan Syariah, LN RI Tahun 2008.

Usanti, Trisadini Prasastinah. "Karakteristik Prinsip Kehati-Hatian Pada Kegiatan Usaha

Perbankan Syariah”. Disertasi--Universitas Airlangga, Surabaya, 2010. dan A. Shomad. "Penyelesaian Pembiayaan Bermasalah Bank Syariah", Laporan

Penelitian, Fakultas Hukum Unair, Surabaya, 2008.

Yahman dan Trisadini Prasastinah Usanti, Bunga Rampai Hukum Aktual Dalam Perspektif Hukum Bisnis Kontraktual Berimplikasi Pidana dan Perdata. Surabaya: Mitra Mandiri, 2011. 